\title{
PENANGANAN ANAK ADHD \\ (ATTENTION DEFICIT HIPERACITIVITY DISORDER) DI MI AMANAH TANGGUNG TUREN
}

\author{
Aisah Novia Sari ${ }^{1}$, Afifatu Rohmawati ${ }^{2}$ \\ Program Studi Pendidikan Islam Anak Usia Dini,Fakultas Tarbiyah, \\ Institut Agama Islam Al-Qolam Malang \\ aisahnovi7@gmail.com, afIfaturohmawati@alqolam.ac.id
}

\section{Info Artikel}

Riwayat Artikel

Diterima : 31 Januari 2020

Disetujui : 29 Februari 2020

Kata Kunci :

Penanganan, Anak ADHD

\section{ABSTRAK}

Abstract: The process of handling ADHD children properly through a form of cooperation built by stakeholders in an educational institution. Qualitative-descriptive research methods (case studies). The results of this research include (1) the process of handling ADHD children through early identification as an effort to reduce the symptoms of ADHD. (2) The role of the teacher in handling ADHD children by showing the pattern of care given by the teacher to children in school. (3) The role of parents in handling ADHD children by showing parenting from parents when at home through a balanced interaction with how to communicate (face to face). (4) The form of collaboration between parents and teachers that can be seen from the intensity of communication through social media or electronic media and letters in evaluating the development of ADHD children. This research can be concluded that the handling of ADHD children through early identification, parenting techniques of teachers and parents as a form of communication to children and the cooperation of teachers and parents.

Abstrak: Proses penanganan terhadap anak ADHD dengan tepat melalui bentuk kerjasama yang di bangun oleh stakeholder dalam suatu lembaga pendidikan. Metode penelitian kualitatifdeskriptif (studi kasus). Hasil penelitian meliputi (1) proses penanganan anak ADHD melalui identifikasi sejak dini sebagai upaya mengurangi gejala ADHD. (2) Peran guru terhadap penanganan anak ADHD dengan menunjukkan adanya pola asuh yang diberikan guru kepada anak di sekolah. (3) Peran orangtua terhadap penanganan anak ADHD dengan menunjukkan adanya pola asuh dari orangtua ketika di rumah melalui adanya interaksi yang seimbang dengan cara melakukan komunikasi (face to face). (4) Bentuk kerjasama antara orangtua dan guru yang terlihat dari intensitas komunikasi melalui media sosial atau media elektronik dan surat dalam mengevaluasi perkembangan anak ADHD. Penelitian ini dapat disimpulkan bahwa penanganan anak ADHD melalui identifikasi sejak dini, teknik pola asuh guru dan orangtua sebgai bentuk komunikasi terhadap anak dan kerjasama guru dan orangtua. 


\section{PENDAHULUAN}

Pada era modern ini banyak sekali anak yang mengidap penyakit ADHD dan banyak dari masyarakat umum yang menganggap bahwa mereka tidak layak untuk bersekolah di sekolah formal berdampingan dengan anak normal. Dikarenakan mereka dianggap terlalu bodoh, gila dan aneh. Terlihat di sekolah MI Amanah terdapat konsep pendidikan inklusif yang sangat penting untuk memahami, dan mengetahui sejak dini dalam mengidentifikasi berbagai penyimpangan pertumbuhan, perkembangan dan sikap sosial emosional terhadap anak. Sehingga, dapat dilakukan penanganan yang sesuai dengan permasalahan yang dialami. Khususnya guru kelas harus bisa menangani apabila terdapat anak yang berbeda dengan yang lain, seperti pada anak ADHD. Hal perlu diketahui bahwa di sekolah MI Amanah, anak ADHD sangat diperhatikan dan mengalami perkembangan yang begitu pesat dibandingkan teman sekelasnya.

Terlihat permasalahan yang terjadi di sekitar sekolah-sekolah yang di duga juga mendidik anak ADHD. Namun, ditemukan beberapa sekolah tersebut tidak memiliki surat resmi yang menyatakan bahwa anak didiknya adalah anak ADHD dan gurunya pun banyak yang masih di bangku perkuliahan. Selain itu, kemampuan dasar guru masih belum ada yang memiliki bidang keilmuan pendidikan luar biasa. Kemudian ada yang masih lulusan SMA dan belum melanjutkan ke perguruan tinggi untuk studinya.

Pada dasarnya, semua guru PAUD seharusnya bisa menangani apabila mengalami tantangan terhadap anak yang berbeda dalam memberikan fasilitas untuk pendidikannya. Anak yang berbeda tersebut ditunjukkan kepada anak berkebutuhan khusus (ABK) dan anak Attention Deficit Hiperactivity Disorder (ADHD) yang membutuhkan perhatian lebih dibandingkan anak-anak normal lainnya. Karena kita hidup di desa maka wajar saja apabila sekolah MI Amanah juga menerima anak ADHD dan banyak orangtua yang memperhatikan pendidikan untuk anak berkebutuhan khusus (ABK) di sekolah yang sama dengan anak normal. Di tambah jenjang pendidikan terakhir guru di MI Amanah dengan lulusan MA dan lulusan S1. Namun, bukan lulusan psikolog melainkan ada yang lulusan administrasi dan pendidikan anak usia dini.

Pendidikan anak usia dini (PAUD) adalah jenjang pendidikan dasar yang merupakan suatu upaya pembinaan yang ditujukan bagi anak sejak lahir sampai dengan usia delapan tahun yang dilakukan dengan pemberian rangsangan pendidikan untuk membantu pertumbuhan dan perkembangan jasmani dan rohani agar anak memiliki kesiapan dalam memasuki pendidikan lebih lanjut, yang diselenggarakan pada jalur formal, nonformal, dan informal ${ }^{1}$.

Secara umum, anak usia dini memiliki karakteristik meliputi (1) Unik, setiap anak terlahir berbeda karakter antara satu dengan yang lainnya; (2) Egosentris, cenderung melihat sesuatu dari sudut pandang sendiri; (3) Aktif dan

${ }^{1}$ Maimunah Hasan. Pendidikan Anak Usia Dini. (Jogjakarta: diva press, 2009), hal 15 
energik, anak senang beraktivitas; (4) Rasa ingin tahu yang kuat dan antusisas terhadap berbagai hal, anak cenderung banyak bertanya tentang berbagai hal yang baru; (5) Eksploratif dan berjiwa petualang, rasa ingin tahu yang kuat. Sehingga, ingin mencoba dan mempelajari hal-hal yang baru; (6) Spontan, perilaku yang ditampilkan anak relatif asli dan tidak ditutup-tutupi; (7) Senang dan kaya dengan fantasi, anak senang berimajinasi; (8) Masih mudah frustasi, karena sifat anak masih egosentris; (9) Masih kurang pertimbangan dalam melakukan sesuatu, anak masih belum memiliki rasa pertimbangan yang matang; (10) Daya perhatian pendek, fokus perhatian anak masih terbatas; (11) Bergairah untuk belajar dan banyak belajar dari pengalaman; (12) Semakin menunjukkan minat terhadap teman, mulai berminat untuk bersosialisasi. ${ }^{2}$

Pada Undang-Undang RI Nomor 14 Tahun 2005 tentang Guru dan Dosen disebutkan bahwa guru merupakan pendidik professional dengan tugas utama mendidik, mengajar, membimbing, mengarahkan, melatih, menilai, dan mengevaluasi peserta didik pada pendidikan anak usia dini jalur pendidikan formal, pendidikan dasar, dan pendidikan menengah. Sehingga, pendidik sangat penting dalam merancang strategi mengajar untuk mengembangkan keprefesionalan pada dunia pendidikan saat ini.

Strategi yang perlu diterapkan kepada pendidik PAUD yang professional idealnya mempunyai kewajiban meliputi (1) Merencanakan pembelajaran, melaksanakan proses pembelajaran yang bermutu, serta menilai dan mengevaluasi pembelajaran; (2) Meningkatkan dan mengembangkan kualifikasi akademik dan kompetensi secara berkelanjutan sejalan dengan perkembangan ilmu pengetahuan, teknologi serta seni; (3) Bertindak objektif serta tidak diskriminatif atas dasar pertimbangan jenis kelamin, agama, suku, ras, dan kondisi fisik tertentu, ataupun latar belakang keluarga dan status sosial ekonomi peserta didik dalam pembelajaran; (4) Menjunjung tinggi peraturan perundang-undangan, hukum, kode etik pendidik, serta nilai-nilai agama dan etika; (5) Memelihara dan memupuk persatuan dan kesatuan bangsa ${ }^{3}$. Strategi tersebut menjadi tugas keperfesionalan pendidik dan meningkatkan kerjasama dengan orangtua dalam pendidikan anak ADHD.

Peran orangtua berdasarkan teori morrison berpendapat bahwa orangtua adalah kunci dalam membangun keberhasilan pendidikan yang berpusat pada keluarga. ${ }^{4}$ Menurut Rahman, (2002) mengatakan bahwa orangtua sangat berpengaruh terhadap pendidikan anak, sebab orangtua merupakan guru pertama dan utama bagi anak. Pendidikan orangtua dalam keluarga merupakan lingkungan pertama yang diterima anak. ${ }^{5}$ Menurut Richards dan Taylor mengatakan bahwa

\footnotetext{
${ }^{2}$ Syamsu Yusuf dan Nani M. Sugandhi, Perkembangan Peserta Didik, (Jakarta: Rajawali Press, 2011), hal 48-50

${ }^{3}$ Ibid, halaman $92-93$

${ }^{4}$ George S Morrison, Dasar-dasar Pendidian Anak Usia Dini Edisi kelima, (Jakarta: Indeks, 2012) halaman 34

${ }^{5}$ Hibana S. Rahman, Konsep Dasar Pendidikan Anak Usia Dini. (Jakarta: PGTKI Press,2002) halaman 95
} 
peran orangtua dalam pendidikan anaknya sangat penting dalam kegiatan belajar untuk anak. Lewat peran serta aktif orangtua dalam proses belajar anak baik di rumah maupun di sekolah, anak semakin bersemangat mengikuti berbagai kegiatan belajar. ${ }^{6}$

ADHD (Attention Deficit Hiperactivity Disorder) merupakan cacat dimana anak secara konsisten menunjukkan satu atau lebih karakteristik selama satu periode waktu meliputi (1) perhatian tidak fokus; (2) hiperaktivitas; (3) sifat implusif ${ }^{7}$. ADHD merupakan suatu gangguan kronis (menahun) yang dapat dimulai pada masa bayi dan dapat berlanjut sampai dengan dewasa. Gangguan kronis ADHD dapat mempunyai pengaruh negatif terhadap kehidupan anak di sekolah, di rumah, dan di dalam komunitasnya ${ }^{8}$. ADHD adalah suatu kondisi ketika seseorang memperhatikan gejala-gejala kurang konsentrasi, hiperaktif dan implusif yang dapat menyebabkan ketidak seimbangan sebagian besar aktivitas hidup mereka.

Ciri utama gangguan ini adalah adanya kecenderungan untuk berpindah dari satu kegiatan ke kegiatan lain tanpa dapat menyelesaikan tugas yang diberikan, tidak dapat konsentrasi dengan baik bila mengerjakan suatu tugas yang menuntut keterlibatan kognitif. Serta tampak adanya aktivitas yang tidak beraturan, berlebihan, dan mengacau. Dampak ADHD bila tidak diobati, meliputi (a) Meningkatnya resiko untuk gagal dan putus sekolah; (b) Masalah dengan tingkah laku dan disiplin; (c) Kesulitan sosial dan perselisihan keluarga; (d) Luka akibat kecelakaan; (e) Penyalahgunaan alkohol dan obat; (f) Depresi dan gangguan mental lainnya; (g) Masalah dalam pekerjaan; (h) Kecelakaan saat mengemudi; (i) Kehamilan yang tidak diinginkan; (j) Kenakalan remaja, kriminalitas, dan penahanan (oleh yang berwajib) ${ }^{9}$.

Penanganan anak ADHD dan kesulitan belajar bukan sesuatu yang mudah. Sehingga, dibutuhkan kerjasama dari berbagai pihak terpadu. Kerja sama tersebut akan sangat membantu anak dalam mengatasi masalah dan mengoptimalkan potensi belajarnya $^{10}$. Sebaiknya, guru juga lebih memahami karakteristik anak ADHD sesuai dengan tahap perkembangannya. Karena anak ADHD sedikit berbeda dengan anak normal, maka guru harus lebih memperhatikan dalam hal penanganannya.

Adapun tujuan dalam kegiatan penelitian yang tertuang dalam lingkup sekolah ini meliputi Pertama, untuk mendeskripsikan proses penanganan yang diberikan kepada anak ADHD. Kedua, untuk mendeskripsikan peran guru dalam penanganan anak ADHD. Ketiga, untuk mendeskripsikan peran orangtua dalam penanganan anak ADHD. Keempat, untuk mendeskripsikan bentuk kerjasama

\footnotetext{
${ }^{6}$ Colin Richard and Philip Taylor, How Shell We School Our Children? Primary Location and Its Future, (London: Falmer Press, 1998) halaman 124

${ }^{7}$ John W. Santrock. Perkembangan Anak, Jilid 2. (Jakarta: Erlangga. 2007), hal 257

${ }^{8}$ Drs. MIF. Baihaqi, Msi dan Drs. M. Sugiarmin, Mpd. Memahami dan membantu anak ADHD. (Bandung: Refika Aditama. 2006), hal 3

${ }^{9}$ A. Dayu P, Mendidik Anak ADHD . (Jogjakarta: Javalitera, 2014). halaman 38-39

${ }^{10}$ MIF. Baihaqi. Memahami dan Membantu Anak ADHD. (Bandung: PT Refika Aditama, 2008). halaman 71
} 
antara orangtua dan guru dalam penangangan anak ADHD. Penelitian ini berproses dalam mengidentifikasi pemecaham masalah yang terdapat di lembaga pendidikan MI Amanah Tanggung Turen.

\section{METODE}

Penelitian yang dilakukan untuk mendiskripsikan tentang penanganan anak ADHD (Attention Deficit Hiperacitivity Disorder) di MI Amanah Tanggung Turen. Penelitian ini menggunakan pendekatan kualitatif. Pendekatan kualitatif digunakan untuk mengungkapkan data deskriptif melalui informan yang memahami tentang apa yang dilakukan, dirasakan, dan dialami terhadap fokus penelitian. Dimana, peneliti adalah instrument kunci dalam penelitian. Teknik pengumpulan data dilakukan secara triangulasi (gabungan), analisis data bersifat induktif/kualitas dan hasil penelitian kualitatif lebih menekan makna dan generalisasi ${ }^{11}$.

Rancangan penelitian yang digunakan adalah studi kasus (case study) untuk mendiskripsikan penanganan anak ADHD (Attention Deficit Hiperacitivity Disorder) di Mi Amanah Tanggung Turen. Sumber data dalam penelitian ini diambil dari orangtua wali dan guru kelas di MI Amanah Tanggung Turen yang pendidikan guru di sekolah ini masih berada di bangku perkuliahan dan ada yang lulusan S1 namun bukan lulusan psikolog melainkan lulusan administrasi. Sehingga, peneliti ingin mengetahui bagaimana prakteknya dilapangan, terutama di sekolah yang ingin diteliti.

Peran stakeholder, peneliti juga menggunakan dokumen penanganan anak ADHD meliputi Pertama, pemerolehan dokumen dari hasil perkembangan proses belajar anak selama kegiatan belajar dan pembelajaran sekolah secara langsung. Kedua, proses keterlibatan orangtua dan guru dalam bekerjasama untuk penanganan anak ADHD. Data tersebut diperoleh melalui observasi langsung, dokumentasi dan wawancara. Ketiga, peran orangtua dan guru terhadap penanganan anak ADHD dengan menunjukkan adanya pola asuh dari orangtua yang sangat berkesinambungan dalam mengkolaborasikan adanya interaksi yang seimbang dengan cara melakukan komunikasi (face to face).

Menurut Miles dan huberman (1984), mengemukakan bahwa kegiatan dalam analisis kualitatif di lakukan secara interaktif dan berlangsung secara terus menerus sampai tuntas, sehingga datanya sudah jenuh. Kegiatan dalam analisis data, yaitu data reduction, data display dan conclusions drawing/verifying ${ }^{12}$. Penelitian ini, dianalisa dari proses pengambilan data. Kemudian, dilakukan pengecekan untuk keabsahan data dalam penelitian ini melalui proses trianggulasi secara bertahap hingga data yang diperoleh oleh peneliti dirasa sudah cukup.

${ }^{11}$ Sugiyono, Metode Penelitian Kuantitatif Kualitatif dan R\&D, (Bandung: Alfabeta, 2008), halaman 9

12 Ibid. halaman 246 


\section{HASIL DAN PEMBAHASAN}

Berdasarkan fokus topik dalam kegiatan penelitian yang dilakukan oleh pelaksana dalam menganalisis data mengenai penanganan anak ADHD di sekolah dikaitkan dengan praktik dalam menstimulasi perkembangan anak ADHD agar dapat tumbuh dan berkembang sesuai dengan usiannya. Berikut ini pembahasan hasil temuan yang sudah disesuaikan dengan hasil sub fokus, sebagai berikut (1) Penanganan anak ADHD ; (2) Peran guru terhadap penanganan anak ADHD; (3) Peran orangtua terhadap anak ADHD; (4) Bentuk kerjasama antara guru dan orangtua dalam menangani anak ADHD di MI Amanah Tanggung Turen yang telah diananlisis dengan hasil kegiatan penelitian yang dilakukan oleh peneliti.

Pertama, penanganan Anak ADHD di MI Amanah Tanggung Turen, temuan data dari analisis yang ada pada hasil observasi, wawancara dan dokumentasi tentang penanganan anak ADHD melalui proses kegiatan belajar mengajar di sekolah diharapkan dapat mempengaruhi pola dan sikap anak. Karena keterbatasan merekalah yang membuat berbeda dengan teman sebayanya, mengingat pentingnya penanganan untuk anak ADHD. Maka, mereka juga butuh stimulus pembinaan terhadap kemampuannya dasar anak, dukungan dan dorongan untuk bisa tumbuh dan berkembang sesuai dengan usia mereka. Keberhasilan anak ADHD untuk sembuh tergantung pada pola penanganannya. Sehingga, sangat perlu adanya penanganan yang tepat dan mampu menolong mereka untuk tetap tumbuh dan berkembang sesuai pada kemampuan yang dimilikinya.

Sebagaimana, pernyataan menurut Barkley (dalam Dayu, 2014) membahas tentang anak ADHD merupakan anak yang memiliki gangguan ketika kemampuan responsnya terhalang dan mengalami disfungsi pelaksana yang mengarah pada kurangnya pengaturan diri. Lemahnya kemampuan mengatur perilaku untuk tujuan sekarang dan masa depan. Serta, sulit beradaptasi secara sosial dan perilaku dengan tuntutan lingkungan ${ }^{13}$. Karena sikap hiperaktif mereka yang tidak terkontrol hingga menyebabkan kurangnya pengaturan diri. Perlunya penanganan yang tepat agar sikap dan tindakan mereka tetap seimbang.

Berdasarkan pemahaman tersebut, temuan-temuan menunjukkan bahwa anak ADHD yang ada di MI Amanah Tanggung Turen menunjukkan kegiatan dalam proses penanganan yang dapat mengurangi gejala ADHD dengan adanya kemauan anak untuk duduk dengan bersikap tenang ketika menyelesaikan satu tugasnya. Kemudian, anak dapat di ajak komunikasi dua arah walaupun anak masih butuh waktu untuk merespon. Serta, anak dapat memanggil guru di kelas lain sesuai dengan namanya.

Kedua, peran guru terhadap anak ADHD di MI Amanah Tanggung Turen. Guru merupakan tenaga professional dengan kualifikasi akademik tertentu yang bertugas mendidik, mengajar, membimbing, mengarahkan melatih, serta

${ }^{13}$ A. Dayu P. Op.Cit. (Jogjakarta: Javalitera, 2014), hal 29 
mengevaluasi peserta didik pada jenjang pendidikan anak usia dini ${ }^{14}$. Sehingga, keberadaan guru dalam proses penanganan juga sangat penting. Karena guru juga termasuk penentu dalam proses penyembuhan gejala ADHD pada anak. Guru tentu harus mampu menguasai dan memahami setiap karakter perkembangan anak ADHD tanpa adanya deskriminasi melalui proses pemberian layanan pendidikan yang sesuai dengan anak normal.

Martinus menyebutkan beberapa peran penting yang harus dimiliki oleh seorang guru anak usia dini meliputi peran guru dalam berinteraksi, pengasuhan, mengatur tekanan/stress, memberikan fasilitas, perencanaan, pengayaan, penanganan masalah, pembelajaran, bimbingan dan pemeliharaan ${ }^{15}$. Peran tersebut sangatlah penting karena untuk menangani anak ADHD. Guru juga harus memberikan pelayanan yang terbaik. Guru juga harus memberikan pengasuhan dan bimbingan yang tepat agar dalam proses penyembuhan gejala ADHD dapat dilakukan dengan baik.

Berdasarkan hal tersebut, temuan data yang di peroleh menunjukkan adanya penanganan secara tepat. hal ini dapat di lihat dari penerapan pola asuh yang diberikan guru kepada anak ADHD menunjukkan adanya pengurangan gejala ADHD pada anak. Karena guru menggunakan proses penanganannya dengan metode pendekatan personal kepada anak ADHD. Sehingga, kedekatan anak ADHD dengan guru seperti kedekatan orangtua dengan anak dan dalam menyampaikan suatu informasi guru memberikan informasi tersebut dengan cara di ulang-ulang. Sehingga, anak ADHD dapat memahami satu informasi tersebut.

Ketiga, peran orangtua terhadap anak ADHD di MI Amanah Tanggung Turen. Peran orangtua merupakan lingkungan yang pertama dan uama bagi anak. Karena dari keluarga yang paling dekat dengan anak akan mengalami peningkatan proses belajar melalui penerapan peraturan dalam menunjang kemampuan pengetahuan, sikap, dan keterampilannya. Morrison berpendapat bahwa orangtua adalah kunci keberhasilan dalam membangun pendidikan dasar yang berpusat pada keluarga. ${ }^{16}$ Selanjutnya, menurut Rahman mengatakan bahwa orangtua sangat berpengaruh terhadap pendidikan anak, sebab orangtua merupakan guru pertama dan utama bagia anak. Orangtua melalui pendidikan dalam keluarga merupakan lingkungan pertama yang diterima anak. ${ }^{17}$

Peran orangtua sangatlah berpengaruh pada perkembangan anak dikemudian hari. Karena orangtua adalah mitra kerja guru yang baik jika pemikiran orangtua sejalan dengan pemikiran guru. Sehingga, ketercapaian tumbuh dan kembang anak ADHD dapat berhasil. Mitra kerjasama guru dan orangtua bertanggung jawab atas keberhasilan penanganan di rumah. Orangtua bertanggung jawab untuk menangani anak sesuai dengan yang dilakukan oleh guru ketika di

\footnotetext{
${ }^{14}$ Novan Ardy Wiyani, Konsep Dasar PAUD, cetakan 1(Jogjakarta: Gava Media, 2016), halaman 65

${ }^{15}$ Martinus Yamin dan Jamilah Sabri Sanan, Panduan PAUD, (Jakarta: Refrensi, 2013) halaman 32

${ }^{16}$ George S Morrison, Op.Cit halaman 34

${ }^{17}$ Hibana S. Rahman, Op.Cit, halaman 95
} 
sekolah. Oleh sebab itu, orangtua hendaklah selalu melakukan komunikasi secara intens dengan guru dalam mengevaluasi perkembangan anak ketika di rumah.

Proses penanganan yang dilakukan orangtua tidak terlepas dari faktor ekonomi dan intensitas waktu belajar yang diberikan orangtua terhadap anak. Hal tersebut terjadi karena keluarga merupakan bagian terkecil dari sebuah lingkungan. Inilah yang mampu mendasari bahwa orangtua juga merupakan bagan dari masyarakat. Sehingga, interaksi sosial yang terjadi juga berkaitan dengan sosial ekonomi keluarga.

Orangtua dari galih dwi anggara adalah seorang pekerja buruh harian dengan pendidikan terakhir SLTA yang berpenghasilan tidak menentu. Setiap harinya ibu bekerja buruh pabrik yang ada di kota Malang. Hal ini membuat membuat intensitas waktu menjadi berkurang. Setiap hari galih berada di rumah dengan ayahnya saja. Akan tetapi, jika hari minggu kedua orangtuannya dapat menemaninya. Intensitas waktu yang diberikan orangtua terhadap anak ADHD ditentukan juga oleh kesadaran orangtua tentang pentingnya penanganan bagi anak ADHD.

Berdasarkan hal tersebut, hasil temuan-temuan menunjukkan adanya pola asuh dari orangtua yang sangat seimbang karena orangtua dapat bekerja sama dengan guru. Hal ini ditunjukkan dengan adanya interaksi yang seimbang dengan cara melakukan komunikasi dengan sosial media maupun face to face. Pentingnya orangtua dalam memberikan intensitas waktu belajar sebagai pendampingan saat dirumah dengan waktu yang cukup panjang. Pendampingan tersebut dapat ditunjukkan melalui proses pemberian waktu satu hari dalam seminggu untuk memberikan penanganan yang intensif kepada anak ADHD.

Keempat, bentuk kerjasama antara orangtua dan guru dalam menangani anak ADHD di MI Aamanah Tanggung Turen. Keberhasilan dalam menangani anak ADHD tidak hanya diciptakan oleh orangtua saja atau hanya guru saja. Melainkan, kolaborasi sebagai bentuk kerjasama antar keduanya yang dapat mengantarkan pada tingkat ketercapaian dalam penanganan anak ADHD. Karena orangtua adalah penanggung jawab anak ADHD ketika dirumah. Sedangkan, ketika di sekolah penanggung jawab atas anak ADHD adalah guru.

Hal tersebut di perkuat melalui paparan dari Ki Hajar Dewantoro mengungkapkan bahwa pendidikan anak itu berlangsung dalam tiga tahapan meliputi lingkungan keluarga, sekolah dan masyarakat ${ }^{18}$. Hal ini menunjukkan bahwa bentuk kerjasama sangatlah penting dilakukan oleh stakeholder sebagai bentuk kerjasama yang harmonis akan membuat penanganan anak ADHD secara tepat. Lembaga sekolah di MI Amanah melalui bentuk kerjasama yang diterapkan guru dengan orangtua dapat di lihat dari komunikasi melalui berbagai media sosial atau media elektronik. Selain itu, komunikasi orangtua dan guru juga melalui surat yang diberikan guru untuk orangtua. Adapun bentuk kerjasama antara guru dan

\footnotetext{
${ }^{18}$ Ki Hajar Dewantoro, Karya Ki Hajar Dewantoro Bagian I- Pendidikan Bagian II- Kebudayan Cetakan Kedua, (Yogyakarta: Majlis Umum Persatuan Taman Siswa, 1997), halaman 70
} 
orangtua seperti penggalangan dana untuk membangun kelas yang lebih kondusif, pengadaan mainan dan pembelian alat terapi. Selain itu, juga melakukan kerjasama dalam bentuk perancangan kegiatan seperti ulangtahun sekolah, peringatan isra' mi'raj, dan gerak jalan maupun bakti sosial.

\section{SIMPULAN DAN SARAN}

Berdasarkan hasil temuan dalam kegiatan penelitian. Terlihat keabsahan dari hasil temuan-temuan dapat di evaluasi melalui perumusan kesimpulan, meliputi Pertama, penanganan anak ADHD di MI Amanah tanggung turen, temuan hasil data wawancara menunjukkan bahwa anak ADHD yang ada di MI Amanah Tanggung Turen menunjukkan kegiatan dalam proses penanganan yang dapat mengurangi gejala ADHD dengan adanya kemauan anak untuk duduk dengan bersikap tenang ketika menyelesaikan satu tugasnya. Kemudian, anak dapat di ajak komunikasi dua arah walaupun anak masih butuh waktu untuk merespon. Serta, anak dapat memanggil guru di kelas lain sesuai dengan namanya.

Kedua, peran guru terhadap penanganan anak ADHD dari hasil temuantemuan pada kegiatan penelitian menunjukkan adanya penerapan pola asuh yang diberikan guru kepada anak ADHD menunjukkan adanya pengurangan gejala ADHD pada anak. Karena guru menggunakan proses penanganannya dengan metode pendekatan personal kepada anak ADHD. Sehingga, kedekatan anak ADHD dengan guru seperti kedekatan orangtua dengan anak dan dalam menyampaikan suatu informasi guru memberikan informasi tersebut dengan cara di ulang-ulang. Sehingga, anak ADHD dapat memahami satu informasi tersebut.

Ketiga, peran orangtua terhadap penanganan anak ADHD, hasil temuantemuan menunjukkan adanya pola asuh dari orangtua yang sangat seimbang karena orangtua dapat bekerja sama dengan guru. Hal ini ditunjukkan dengan adanya interaksi yang seimbang dengan cara melakukan komunikasi dengan sosial media maupun face to face. Pentingnya orangtua dalam memberikan intensitas waktu belajar sebagai pendampingan saat dirumah dengan waktu yang cukup panjang. Pendampingan tersebut dapat ditunjukkan melalui proses pemberian waktu satu hari dalam seminggu untuk memberikan penanganan yang intensif kepada anak ADHD.

Keempat, bentuk kerjasama antara orangtua dan guru dari hasil temuantemuan menunjukan adanya keberhasilan dalam menangani anak ADHD tidak hanya diciptakan oleh orangtua saja atau hanya guru saja. Melainkan, kolaborasi sebagai bentuk kerjasama antar keduanya yang dapat mengantarkan pada tingkat ketercapaian dalam penanganan anak ADHD. Karena orangtua adalah penanggung jawab anak ADHD ketika dirumah. Sedangkan, ketika di sekolah penanggung jawab atas anak ADHD adalah guru dari segala proses aktivitas anak.

Adapun saran-saran yang dikemukakan, meliputi dalam penanganan anak ADHD keberadaan keluarga juga memiliki peran yang sangat penting. Sehingga sekolah diharapkan dapat bekerja sama dengan orangtua agar penanganan anak 
ADHD dapat terbangun dengan sebaik-baiknya. Serta, pihak sekolah juga harus memperhatikan kebutuhan anak ADHD, mengingat kebutuhan mereka juga berbeda dengan anak-anak normal pada usianya seperti di sekolah MI Amanah terpenuhinya kebutuhan anak ADHD dalam hal aktivitas fisiknya sudah dapat tertangani dengan baik. Diharapkan buku panduan belajar anak-anak bisa diperbarui kembali. Agar pemanfaatan media pembelajaran bisa digunakan secara sempurna. Hal tersebut menjadi pemenuhan standar kualifikasi guru yang ada, diharapkan agar ada salah satu guru yang paham tentang tumbuh kembang anak. Mengingat anak ADHD berbeda dengan anak-anak normal pada umumnya tentunya tumbuh dan kembangnya pun juga berbeda. Keluarga menjadi lingkungan yang paling dekat dengan anak, diharapkan orangtua dapat menjadi motivator dan selalu memberikan dorongan dan semangat kepada anak ADHD. Agar tumbuh dan kembang anak ADHD juga belangsung dengan optimal.

\section{DAFTAR RUJUKAN}

Dayu. P (2014). Mendidik Anak ADHD. Yogyakarta: Javalitera

Abdurrahman \& Mulyono (2012). Anak Berkesulitan Belajar. Jakarta: PT Rineka Cipta

Baihaqi, M.I.F (2008). Memahami dan Membantu Anak ADHD. Bandung: PT Refika Aditama

Hasan, M., (2009). Pendidikan Anak Usia Dini. Yogyakarta: Diva Press

Morisson, G. S., (2012). Dasar- dasar Pendidikan Anak Usia Dini. Jakarta: Indeks

Rahman, H. S., (2002). Konsep Dasar Pendidikan Anak Usia Dini. Jakarta: PGTKI Press

Richard, Colin and Philip Taylor (1998). How Shell We School Our Children? Primary Location and Its Future. London: Falmer Press

Santrock, John W (2007). Perkembangan Anak. Jilid 2. Jakarta: Erlangga

Sugiyono, (2008). Metode Penelitian Kuantitatif Kualitatif dan R\&D. Bandung: Alfabeta.

Wiyani, Novan Ardy (2016). Konsep Dasar PAUD. Yogyakarta: Gava Media

Yamin, M dan Jamilah, S. S., (2013). Panduan PAUD. Jakarta: Refrensi

Yusuf, Syamsu dan Nani M. Sugandhi (2011). Perkembangan Peseta Didik. Jakarta: Rajawali Press 